\title{
A Functional Perspective of Aversive Control in Psychological Therapy
}

Jesús Alonso-Vega, Nerea Caru Galván-Domínguez, Rocío Castaño-Hurtado, Miguel Núñez de Prado-Gordillo, María Xesús Froxán-Parga*. Universidad Autónoma de Madrid. Correspondence author*: mxesus.froxan@uam.es

\section{Introduction:}

Aversive methods of behavior control have been the subject of controversy for decades, at the center of an intense debate in which the arguments are often based on myths, prejudices and opinions, rather than on data and empirical evidence. The term aversive control refers to techniques involving annoying or unpleasant stimuli to generate behavioral change. Obviously, the use of this kind of stimulus must be authorized within the ethical framework of psychology (Cáceres, 1993; Lerman, \& Vorndran, 2002).

The aversive control of behavior can be found in natural settings (i.e. natural contingencies that have not been arranged by the professional manipulation of aversive stimuli) and it can be found in health care systems; it does not matter whether the professionals are aware of it or not. In such case, it is necessary to understand how aversive control works because we can use it as a tool to promote behavioral changes. We decided to focus on aversive verbal control because we consider that therapist-client verbal interaction is the catalyst for the learning processes that lead to clinical change.

Table 1

Sample characteristics

\begin{tabular}{|c|c|c|c|c|c|c|}
\hline \multicolumn{2}{|c|}{} & \multicolumn{2}{|c|}{ Therapist characteristics } & \multicolumn{2}{c|}{ Client characteristics } \\
\hline Case & $\begin{array}{l}\text { Number } \\
\text { of } \\
\text { sessions }\end{array}$ & Sex, Age & $\begin{array}{l}\text { Years of } \\
\text { experienc } \\
\text { e }\end{array}$ & $\begin{array}{l}\text { Interventio } \\
\text { n model }\end{array}$ & $\begin{array}{l}\text { Sex, } \\
\text { Age }\end{array}$ & Problem \\
\hline 1 & 10 & $\begin{array}{c}\text { Female, } \\
45\end{array}$ & 16 & Behavioral & $\begin{array}{c}\text { Femal } \\
\text { e, 32 }\end{array}$ & $\begin{array}{c}\text { Problems with } \\
\text { her couple and } \\
\text { in-laws }\end{array}$ \\
\hline 2 & 8 & $\begin{array}{c}\text { Female, } \\
44\end{array}$ & 15 & Behavioral & $\begin{array}{c}\text { Femal } \\
\text { e, 36 }\end{array}$ & $\begin{array}{c}\text { Anxiety crises } \\
\text { related to } \\
\text { different } \\
\text { contexts }\end{array}$ \\
\hline 3 & 8 & Male, 32 & 6 & Behavioral & $\begin{array}{c}\text { Male, } \\
42\end{array}$ & Low mood \\
\hline
\end{tabular}

eferences:

Caceres,J. (1993). Técticas aversivas. En F. Labrador,

Cicta (pp. 558-276), Madrid: Pirámide.

Lerman, D. C., \& Vorndran, C. M. (2002). On the status of knowledge for using punishment: Implications for treating behavior
disorders. Journal of Applied Behavior Analysis, 35(4), 431-464.

\section{Aim:}

The purpose of this work is to analyze the use of verbal aversive control by the therapist during the clinical interaction, combining respondent and operant explanations.

\section{Method:}

To conduct this study, 26 complete therapy sessions from 3 cases with different psychological problems, treated by 3 therapists with different experience level, were analyzed. The therapists' and clients' verbal behavior was categorized with the Sistema de Categorización del Control Verbal Aversivo en Terapia (Categorization System for the Aversive Verbal Control in Therapy), which consists of 8 categories for therapists and 2 categories for clients (see Table 2). Also, the software The Observer XT 12.5 (Noldus ${ }^{\circledR}$ ) was used for the observation, categorization and to calculate the agreement percentage and the intra- and interobserver reliability. The statistical analysis was made with Excel 2016 (Microsoft ${ }^{\circledR}$ ) and IBM SPSS Statistics $24\left(\right.$ IBM $\left.^{\circledR}\right)$.
Results:

As we can see in Table 3 , there is a positive and significant contingency relationship between the clients 'Anti-therapeutic Verbalizations and the therapists' Contingent Aversive Blocks, being especially strong among the In-session Antitherapeutic Verbalizations and Contingent Aversive Blocks ( $\mathrm{Q}$ of Yule $=0.91$ ).

In the case of the clients' In-session Description of an Out-of-session Anti-therapeutic Behavior, the strongest positive and significant contingency relationship is with another $I n$-session Description of an Out-of-session Anti-therapeutic Behavior.

Also noteworthy is the existence of a significant but negative contingency relationship between the clients' In-session Description of an Out-ofsession Anti-therapeutic Behavior and the therapists' Aversive Pairings and Instructional Discriminative, as well as with the clients' Insession Anti-therapeutic Verbalizations. As for the latter, they also maintain a significant negative relationship with the therapists' Abolishing Operations and Establishing Operations.
Table 2

Sistema de Categorización del

Control Verbal Aversivo en Terapia

(COVAT)

\begin{tabular}{c}
\multicolumn{1}{c}{$($ Therapist categories } \\
\hline Aversive categories \\
\hline Aversive Verbalization \\
Aversive Association: \\
$-\quad$ Aversive Pairing \\
$-\quad$ General Abolishing Operation \\
$-\quad$ Personalized Abolishing Operation \\
\hline Non-aversive categories \\
\hline Establishing Operation \\
Instructional Discriminative \\
\hline Aversive Blocks \\
\hline Contingent Aversive Block \\
Non-contingent Aversive Block \\
\hline \multicolumn{1}{c}{ Client categories } \\
\hline In-session Anti-therapeutic Verbalizations
\end{tabular}

In-session Description of an Out-of-session Anti-therapeutic Behavior

de Técnicas de Modificacióny

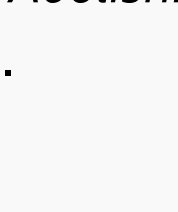

\section{Conclusions:
Aversive verbal control is based both on}

Aversive verbal control is based both on
Pavlovian and operant mechanisms, and one cannot be studied without the other because they are intrinsically interconnected. Indeed, aversive verbalizations can function as punishments because they previously acquired their aversive qualities through Pavlovian conditioning processes. Likewise, aversive verbal counterconditioning works to reduce behaviors because the subject learns to avoid them, through a negative reinforcement process (operant). The potential effects of aversive verbal control may affect behaviors that are happening when and where it is applied, those that happen in different times and places, and even ones that have never happened. Hence, aversive verbal control has great utility in reducing, eliminating and/or preventing antitherapeutic behaviors.

\section{Table 3}

Contingency relationships between the clients' antitherapeutic behaviors and the therapists' and clients' behaviors (delay +1 )

\begin{tabular}{|c|c|c|}
\hline & $\begin{array}{l}\text { In-session Anti-therapeutic } \\
\text { Verbalization }\end{array}$ & $\begin{array}{l}\text { Description of an Out-of-- } \\
\text { session Anti-therapeutic } \\
\text { Behavior }\end{array}$ \\
\hline $\begin{array}{l}\text { Contingent Aversive } \\
\text { Block }\end{array}$ & $\begin{array}{c}\mathrm{r}=22,64^{*} \\
\mathrm{Q}=0,91\end{array}$ & $\begin{array}{l}r=5,86^{*} \\
Q=0,51\end{array}$ \\
\hline $\begin{array}{l}\text { Non-contingent } \\
\text { Aversive Block }\end{array}$ & $\begin{array}{l}\mathrm{r}=-2,38^{*} \\
\mathrm{Q}=-1,00\end{array}$ & $\begin{array}{l}\mathrm{r}=-0,02 \\
\mathrm{Q}=-0,01\end{array}$ \\
\hline $\begin{array}{l}\text { Aversive } \\
\text { Verbalization }\end{array}$ & $\begin{array}{c}\mathrm{r}=17,06^{*} \\
Q=0,84\end{array}$ & $\begin{array}{l}\mathrm{r}=-0,42 \\
\mathrm{Q}=-0,05\end{array}$ \\
\hline Aversive Pairing & $\begin{array}{l}\mathrm{r}=-3,80^{*} \\
\mathrm{Q}=-0,48\end{array}$ & $\begin{array}{l}\mathrm{r}=-3,24^{*} \\
\mathrm{Q}=-0,69\end{array}$ \\
\hline $\begin{array}{l}\text { Personalized } \\
\text { Abolishing } \\
\text { Operation }\end{array}$ & $\begin{array}{l}r=-2,43^{*} \\
Q=-0,40\end{array}$ & $\begin{array}{l}r=-1,44 \\
Q=-0,35\end{array}$ \\
\hline $\begin{array}{l}\text { Generalized } \\
\text { Abolishing } \\
\text { Operation }\end{array}$ & $\begin{array}{l}r=-1,49 \\
Q=-1,00\end{array}$ & $\begin{array}{l}r=-1,49 \\
Q=-1,00\end{array}$ \\
\hline $\begin{array}{l}\text { Establishing } \\
\text { Operation }\end{array}$ & $\begin{array}{l}r=-5,86^{*} \\
Q=-0,60\end{array}$ & $\begin{array}{l}\mathrm{r}=-0,08 \\
\mathrm{Q}=-0,01\end{array}$ \\
\hline $\begin{array}{l}\text { Instructional } \\
\text { Discriminative }\end{array}$ & $\begin{array}{l}\mathrm{r}=-3,33^{*} \\
\mathrm{Q}=-0,70\end{array}$ & $\begin{array}{l}\mathrm{r}=-2,17^{*} \\
\mathrm{Q}=-0,74\end{array}$ \\
\hline $\begin{array}{l}\text { In-session Anti- } \\
\text { therapeutic } \\
\text { Verbalization }\end{array}$ & $\begin{array}{l}r=0,77 \\
Q=0,07\end{array}$ & $\begin{array}{l}r=2,55^{*} \\
Q=0,27\end{array}$ \\
\hline $\begin{array}{l}\text { Description of an } \\
\text { Out-of-session Anti- } \\
\text { therapeutic } \\
\text { Behavior }\end{array}$ & $\begin{array}{l}r=-0,73 \\
Q=-0,10\end{array}$ & $\begin{array}{l}r=8,37 * \\
Q=0,72\end{array}$ \\
\hline
\end{tabular}

